\title{
Climate change impacts and product lines
}

\author{
Szenteleki, K., Ladányi, M., Gaál, M. \& Hegedüs, A. \\ Corvinus University of Budapest, Department of Mathematics and Informatics
}

\begin{abstract}
Summary: This paper summarizes the main effects of extreme weather events on agricultural production and demonstrates their economic consequences. For cost-benefit analysis of economic impacts and for determination of risk levels simulation models are needed that contains the relationship between product line levels and elements. WIN-SIM model is developed for this goal, specialized for wine production. The model is suitable to analyze the market share, the cost and income relations as well as the relation structure of the product lines. The four levels of the model (site, vine growing, wine production and wine market levels) have individual values added from the aspect of end product, where the product line sets out from the site level and gets through the levels up to the consumer segments. Theoretically, all elements can be connected to any element of the next level and sublevel, but there are "prohibited contacts" because of professional, regulation or production practice reasons.
\end{abstract}

Key words: climate change, risk, horticulture, product line, modelling

\section{Introduction}

Many companies - first of all in the industrial sector have begun to act in a variety of ways to develop new product lines that release less carbon to the atmosphere. It is also very important to minimise the impact of the entire food chain on climate change. Among the activities of food chains, that have an impact on environment, we can list: production methods; choice of species and varieties; transport distance and mode, efficiency and scale of energy use; packaging intensity and waste prevention and management practices; GHG emissions and air pollution linked to conservation and preparation $(E C, 2009)$. But in the same time climate change has several impacts on agricultural production, too.

To make deliberate decisions growers and higher level decision makers need detailed information about the possible product lines and their characteristic from the decision aspect, whether the decisions are conscious, occasional or obligate (Herdon, 2009; Herdon \& Rózsa, 2008). Appropriate amount of information helps to develop the most favorable product lines (products), to increase the market share and to optimize the production (Lakner \& Procházka, 2003; Szenteleki et al., 2008).

\section{Climatic risks and their consequences}

Production conditions and safety are strongly depending on extreme weather events. The frequency and intensity of anomalies are expected to increase in Hungary (Bartholy et al., 2007; Révész, 2008). The most important extreme events in Hungary are spring frost, drought as well as heat waves and storms such as wind storms, hail and heavy rains.
Weather extremes involve troubles in plant development or physiological disorders (cracking, sunburn, nutrient uptake disorder) which results production deficit and/or quality defects. Injuries caused by unbalanced water supply or hail are gaps of infections that can so occur suddenly and seriously. Milder winters are favourable for pests and diseases because of less mortality in dormancy periods which can lead to greater damages in the next vegetation period (Gaál et al., 2009). In fruit plantations and vineyards unfavourable weather moreover, can cause damages not only in the current but also in the following years.

Because of climatic risk factors new types of agrotechnics can be necessary which involves changes in production costs. Cost calculations have to contain damage prevention and mitigation as well. The issue is more on prevention because prevention costs are in most cases much less than mitigation costs. One of the most effective prevention methods is appropriate site and variety selection. Technical innovations and investments are also needed to be built in production technology which can result modified production and market structure (Figure 1).

One of the reasons of production cost increase is that irrigation and vapourization become necessary even in moderately intensive cultivars. The yield loss caused by the expected decrease of precipitation and more frequent droughts can be mitigated this way effectively. In some regions the prevention of damages with hail and windstorm indicate expensive investments to avoid high probability yield loss. The calculations have to be executed according to site and plantation, the risk analysis have to be elicited based on observed weather, production and market data and the decision has to be made by the costs of the planned investment, too. Spring and early fall frost events should be 
considered as risk factors of high importance. In case of extreme high risk the ceasing of production of some varieties and/or at some sites should be deliberated.

Negative effects of extreme weather events can partly be compensated by capital investments or high level technology. Expensive investments such as hail or wind protection or irrigation systems require long time capital expenditure. In this case the liquidity of producers decreases which involves price increase.

Sites and varieties with long time experience have to be checked whether they are suitable for production under climate change. Some varieties respond to climate change with yield or quality loss, therefore their production cost is expected to increase. In case in other regions these plants can be grown under more favourite circumstances with lower production costs, domestic growers can become to be at disadvantage. However the longer growing season and higher temperature may favour introduction of some new crops/varieties. One of the solutions in these cases is to change the product palette finding new products which can address a different segment of market or even gains the old consumers back. For this a very thoroughly designed system of variety and technology is needed.

In case the demand of some products decreases, the reasons can usually be found in trend or price structure. Focusing on more profitable substitution products is highly recommended in this case (Figure 1).

If the change of variety and/or technology is executed along a well-designed and thoroughly-proved decision analysis, the value of a production can increase with climate change. Despite of increasing production costs and prices productions can remain profitable if quality is highly respected.

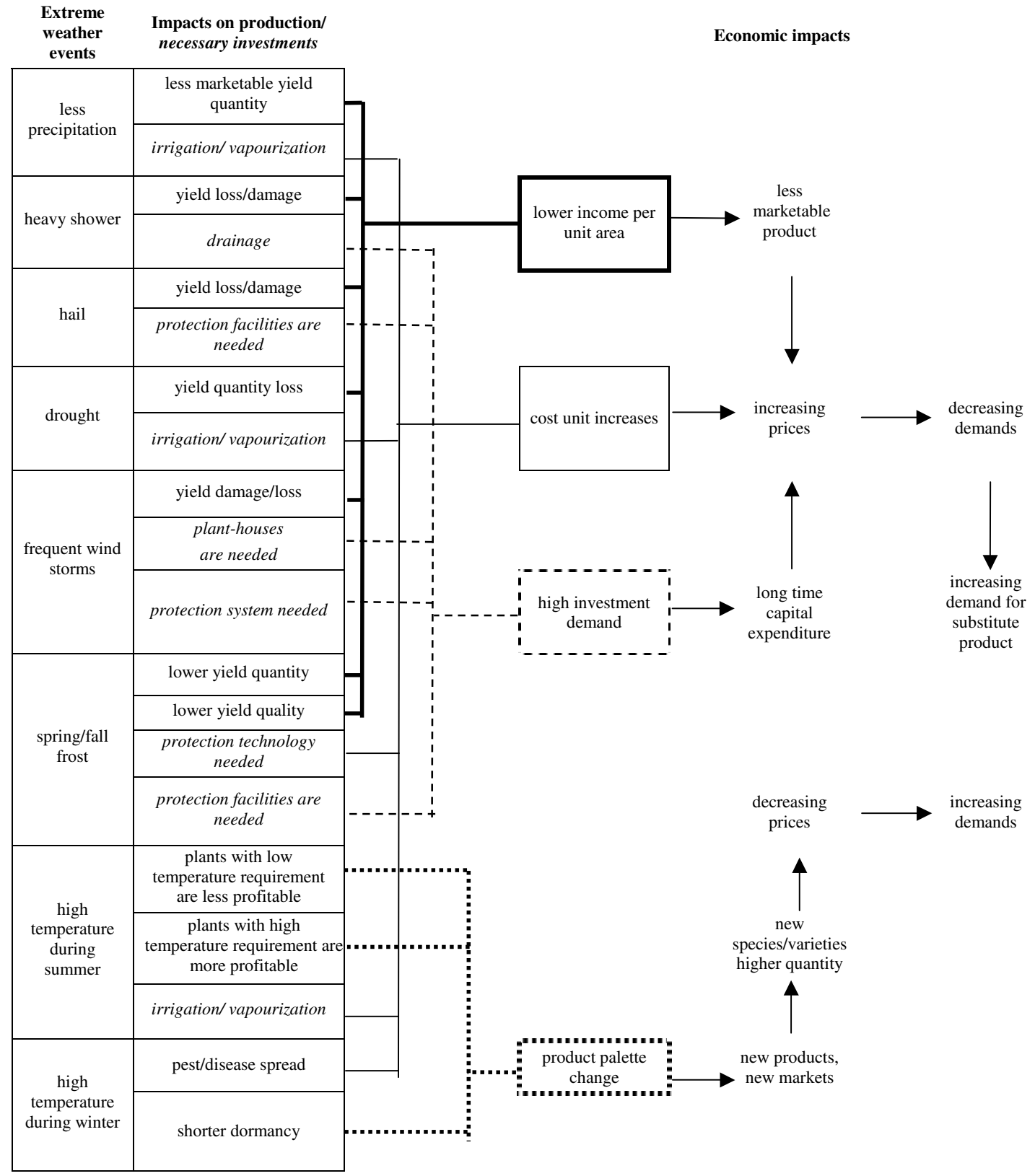

Figure 1. Climatic risk factors and their economic impacts. 
New technology requires new approach with focusing on quality instead on quantity. Growers of products of high quality even with higher prices can manage cost and price increase more flexibly than those of cheaper mass productions.

\section{Product line analyses and modelling}

Simulation is of high importance in climate change research. Thus "What if" type questions can be answered and risk optimization can be made according to the risk strategies of the decision makers. In case models are completed with stochastic elements, the risk functions can be evaluated more precisely for a certain variety or region.

For cost-benefit analysis of economic impacts and for determination of risk levels simulation models are needed that contains the relationship between product line levels and elements. The models make possible to evaluate, compare and filter the product lines. For example in case of climate change certain mitigation or protection investment can be considered profitable from a point of view, while it can be labelled as unprofitable by another decision maker having unfavourable market position.

\section{Characterisation of the elements and the structure of a product line}

From technological, economic and management aspects it is important to

- lay down the production levels and elements, the duties as well as the potential values added;

- describe and evaluate the levels and sublevels;

- define the elements within levels and sublevels and clarify the differences between them;

- outline the relation among the elements according to their functional role;

- fix the prohibited contacts ('no') and permitted contacts ('yes') regarded to the connections between the elements in order to make clear the real operational possibilities in the system;

- provide the system with technological, production cost and sales income data in order to be able to calculate and compare the production potential and competitiveness of the different production systems, strategies or regions.

Product line analysis has been executed now for wine sector in Hungary (Botos et al., 2008). The base model has four main and ten sublevels (Figure 2.). The economic weight (market share) of the elements and the transition probabilities (\%) should be estimated level by level.

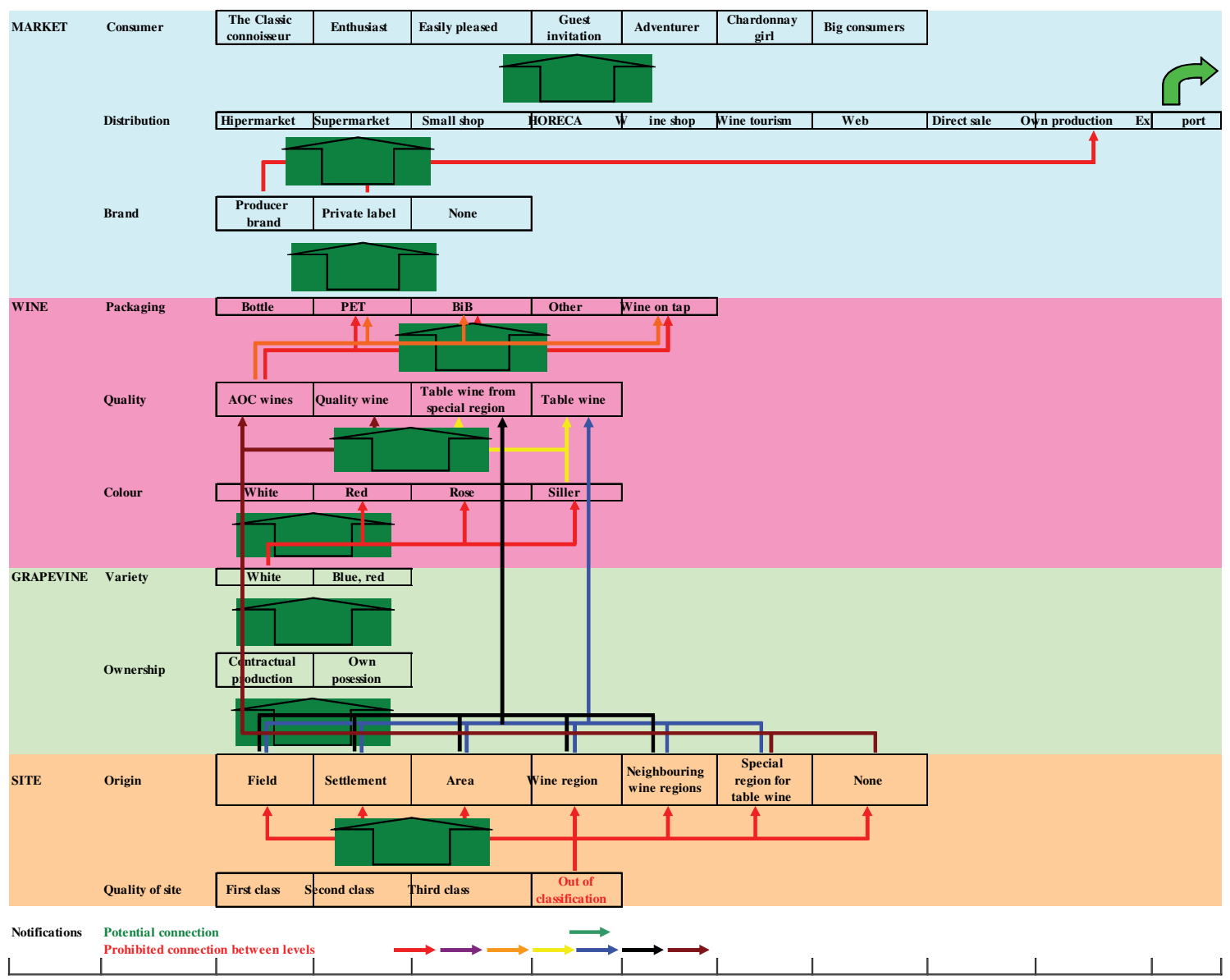

Figure 2. Vertical base model of Hungarian wine sector 
It would be necessary to develop product line analyses for the most important species/varieties in other horticultural sectors, too.

\section{The WIN-SIM software}

The program is developed in Access and is able to process some 70.000 records with a variety of analysis possibilities.

The distributions of the transition probabilities (\%) and the market share can be assumed as normal or beta distributions. The estimations of

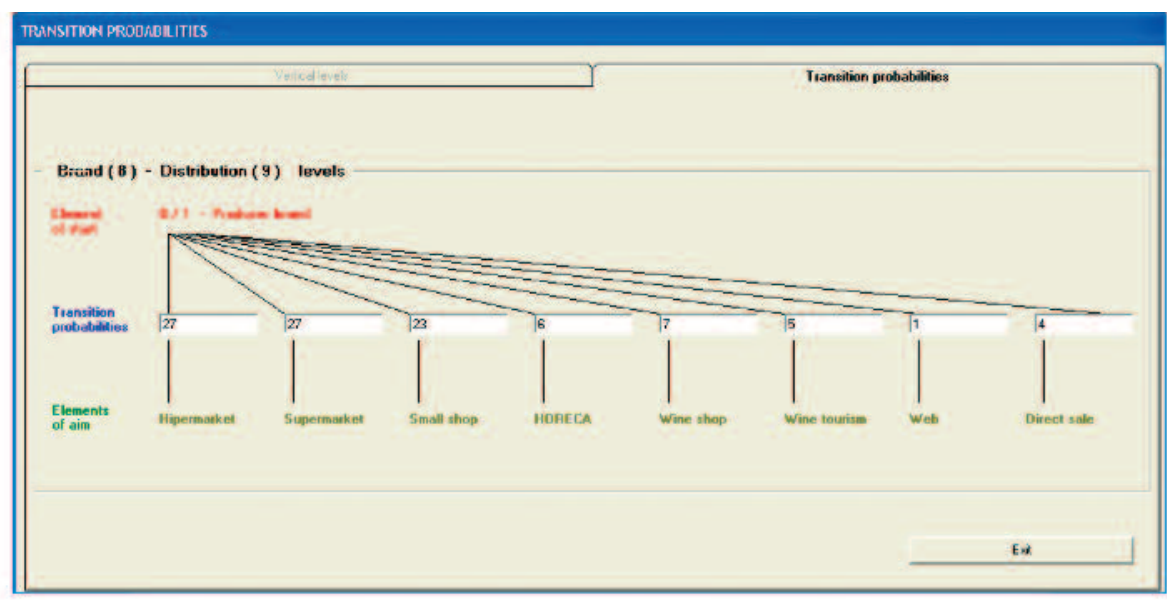

Figure 4. Definition of transition probabilities (\%) by the sector levels expectations and variances can be made by research results, economic calculations and experiences. All the levels except the first one require only one of the following data: market share and transition probabilities, however it is recommended estimating both. The necessary data set contains also the cost and benefit data as well as the added value data in percent.

Working with the software first the vertical, next the horizontal levels and elements should be defined (Figure 3).

Then the market share and the transition probabilities (\%) should be given. The market share relative to the certain levels can be input in one step while the transition probabilities have to be given element by element (Figure 4).

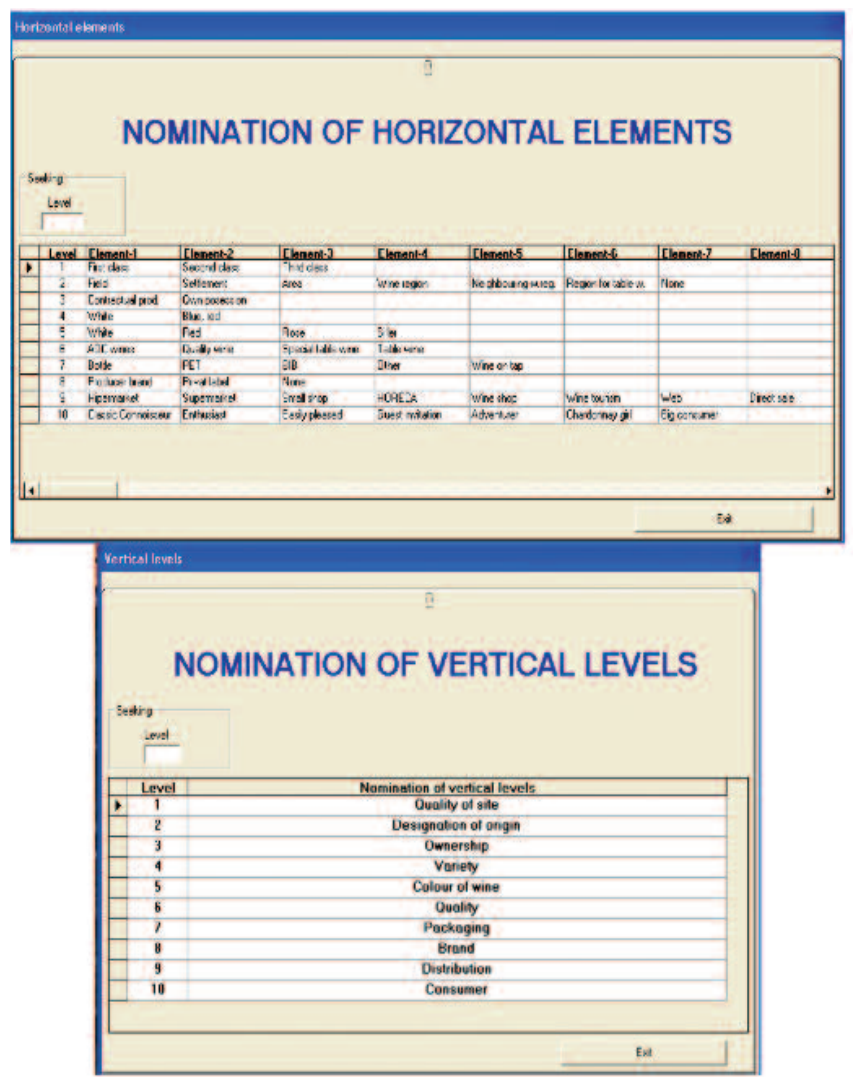

Figure 3. Input of the vertical and horizontal levels in WIN-SIM

The prohibited relations can be defined by setting the transition probability to zero.

Within a certain horizontal level the user can define the weights of the elements as well as the ratios of costs and sales incomes related to the elements. The ratios of costs and sales incomes express the deviation from the means in proportion.

Results can be obtained for all the product lines comparatively or just for a group of them. There are further possibilities to evaluate and filter the results. One can set the level or levels and the element or elements on which a product line or a set of product lines should be evaluated (Figure 5).

The user can make more complex analysis, too. These results appear in table form and can be ordered according to the market share, income, cost or profit. In this option each product line can be evaluated individually or comparatively.

Due to the climate change the species structure of vine plantations may be significantly altered. Dessert grapes, late ripening vines and red wines may be given a greater role in production. The market for grapes and wines may be altered. Red wines may become more competitive with both exports and imports (Botos \& Hajdú, 2006). All these lead to the modification of product lines, too. The market share and the transition probabilities values must be newly estimated.

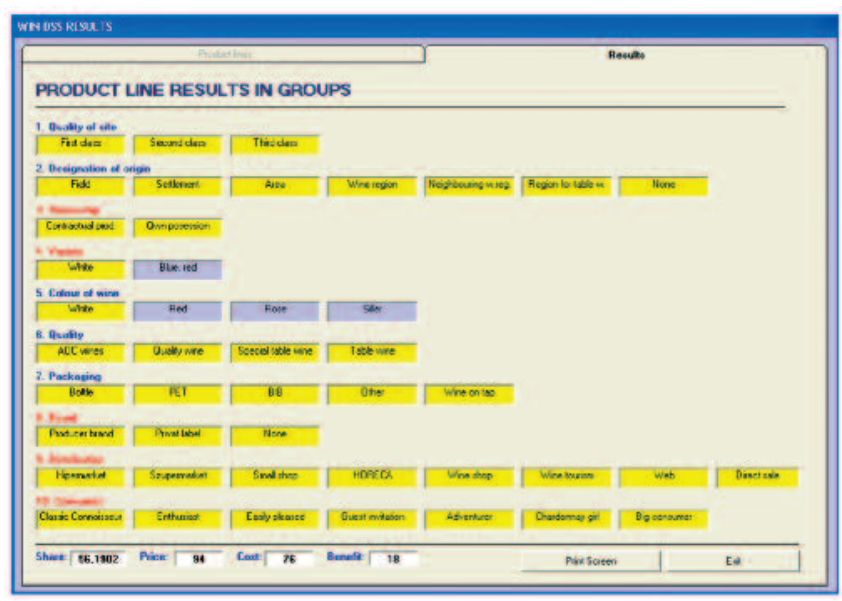

Figure 5. Evaluation of white vine product lines 


\section{Acknowledgements}

The research was financially supported by the OM-00265/2008 and OTKA K 63065/2006 projects.

\section{References}

Botos, E.P. \& Hajdú, E. (2006): A klímaváltozás hazai hatásai és az azokra adható válaszok a szőlészetben, valamint a borászatban. In: Csete L., Nyéki J. (szerk): Klímaváltozás és a magyarországi kertgazdaság. "AGRO-21" Kutatási Programiroda, Budapest

Botos, E.P., Szabó, A. \& Szenteleki, K. (2008): Szőlő termékpályák szimulációs modellezése. Borászati Füzetek, 2008 (6): 9-12.

European Commission (2009): II. Scar foresight excercise - New challenges for agricultural research: climate change, food security, rural development, agricultural knowledge systems. EC, Luxembourg
Gaál, M., Ladányi, M., Szenteleki, K. \& Hegedüs, A. (2009): A kertészeti ágazatok klimatikus kockázatainak vizsgálati-módszertani áttekintése. „KLÍMA-21” Füzetek, 58: 72-81.

Herdon, M. (2009): Impacts of e-collaboration tools for development of rural areas. In: 4th Aspects and Visions of Applied Economics and Informatics, Debrecen, Hungary, 26-27 March., p. 952-959.

Herdon, M. \& Rózsa, T. (2008): DSS for selection and evaluation of information system. In: SMEs. In Information Systems in Agriculture and Forestry XIV European Conference, Prága, Czech Rep., 13-14 May, p. 1-7.

Lakner, Z. \& Procházka, P. (2003): European Wine Economy, St. István University Budapest, p. 307.

Révész, A. (2008): Stochastic behaviour of heat waves and temperature in Hungary. Applied Ecology and Environmental Research, 6 (4): 85-100.

Szenteleki, K., Horváth, L. \& Ladányi, M. (2008): Climate analogies and risk analysis in the Hungarian viticulture. In: World Conference on Agricultural Information and IT, Tokyo, Japan. 24-27 august, 389-396. 